\title{
Nexus Between Online Marketing Strategies and Market Performance: A Critical Review of the Literature and Research Agenda
}

\author{
Annstellah gakii* Samuel maina \\ School of Business, Kenyatta University, PO box 44008-00100 Nairobi, Kenya
}

\begin{abstract}
Online marketing referrers to as internet marketing meaning it requires live internet connection to work. Online marketing strategy is a subset of digital marketing. Organizations raise their sales turnover, market share and profitability using online marketing strategies. For effective control of organizations, marketing managers must depend on well founded and accurate measures of market performance. These market performances comprise profits, sales and market share among many others. The purpose of the study was to conceptualize and examine the conceptual literature, empirical literature, theoretical \& methodological gaps and propose a conceptual model for implementation of the relationship between online marketing strategies and market performance. Discuss the techniques used to operationalize this concept and make it understandable for research participants and beneficiary of the study who are the scholars, policy makers, general public and government for the proper implementation of the idea was also examined. The theories underpinning the study include unified theory of acceptance and use of technology, the behavioral adoption theory, innovation diffusion theory, technology organization environmental framework, industrial organization theory and porters five forces model. The study recommends Positivism philosophy, mixed method research designs employed, the tours and travel agencies in Nairobi Kenya contextual aspect, Semi structured questionnaire for data collection, multiple regression for data analysis and Factor analysis for testing indicators of online marketing strategies and market performance.
\end{abstract}

Keywords: Online marketing strategies, competitive advantage, market performance, firm characteristics

DOI: $10.7176 / \mathrm{EJBM} / 11-15-12$

Publication date:May $31^{\text {st }} 2019$

\section{Introduction}

Online marketing strategy being a subset of digital marketing is traced back from introduction of digital marketing in 1980's. Digital marketing could be traced back in 1980's but was first used in 1990's (Monnappa, 2018). According to Reilly Media (2008) the first online advertisement appeared in 1993 after years of created internet application tool. Digital marketing is basically a term that is used to include both on the internet and off the internet digital technologies and multiple channels under it while online marketing strategies contains activities only on the internet (Aleksandar \& Olja, 2017). Therefore, online marketing strategies could be used interchangeable as internet marketing strategies (Aleksandar \& Olja, 2017). Internet has become a tremendous substantial vehicle for marketing purposes and become front-end application of intelligence of the consumer and as well as their purchase applications (Omar, Bathgate \& Nwankwo, 2011).

In a competitive environment, organizations in Kenya are able to raise their sales turnover, market share and profitability using online marketing strategies (Smith \& Chaffey, 2008). Online marketing strategies are worldwide 
strategies that have enhanced numerous success stories across the globe. Every sales turnover of an organization has been characterized by market performance which comprises profits, sales and market share. For effective control of organizations, marketing managers must depend on well founded and accurate measures of market performance (Barone \& DeCarlo, 2012). The application of different online marketing strategies is used to ensure that a business registers positive results and improve market performance in the industries.

Differentiation strategy builds up entry barriers to potential competitors by building customer and brand loyalty through quality offering and advertising (Wen-Cheng, et al., 2011). Organizations today need to have a well defined competitive advantage strategy to keep up with with changing online marketing strategies for effective market performance. Zapata-Cantu (2016) indicated innovation as a key factor that influences performance, longterm survival and sustainability of the firm.

The purpose of the study was first to conceptualize and examine the conceptual literature on the constructs of online marketing strategies and market performance. Secondly, the study reviewed empirical literature and empirical gaps emerging from linkage between online marketing strategies and market performance. Thirdly, theoretical gaps, methodological gaps were discussed that form basis for future research on online marketing strategies and market performance. Lastly, the study proposed a conceptual model for implementation of the relationship between online marketing strategies and market performance. The paper also discussed the techniques used to operationalize this concept and make it understandable for research participants and beneficiary of the study who are the scholars, policy makers, general public and government for the proper implementation of the idea.

This study was undertaken to show the linkages that exist between online marketing strategies and market performance. This study was considered valuable in a number of ways. First, Different theories and models have been used to explain the concept of performance in general. However, there is lack of commonality on theories and models that are used to anchor market performance (Salindal, 2018 ; Kumar, Boesso \& Favotto, 2012). This paper goes beyond the scope to show theoretical and empirical linkages between online marketing strategies and market performance. Secondly, the study consider the mediating effects of competitive advantage and moderating conditions for firm performance as a link between online marketing strategies and market performance. Lastly, the use of different market performance constructs by different authors (Gunday, Ulusoy, Kilic \& Alpkan, 2012; Kumar, Boesso \& Favotto, 2012; Grawe, Chen \& Daugherty, 2009). This being a contradiction there is need to seek commonality based on different market environment or economies.

\section{Conceptualization of key constructs}

This section of the study discusses some of the concepts that are emerging from this study which include online marketing strategies, competitive advantage, firm characteristics and market performance and gives commonalities and controversies of these variables. The discussion below is mainly on the four main constructs; online marketing strategies, competitive advantage, firm characteristics and market performance.

\subsubsection{Online marketing strategies concept}

Researchers have tried to categorize online marketing strategies into different groups since the invention time. Data of any form can be transferred through the internet networks in form of a text, graphics, videos, content and voice. Sarah Burke (2017) Posit conversational marketing, video marketing, content marketing, email marketing 
and social media marketing are indicators of online marketing strategies. Further Morton (2014) included some of the constructs that are used as online marketing strategies being content marketing, email marketing, social media marketing, search engine marketing, website, banner advertising and mobile marketing.

Online marketing strategies consolidate website, search engine marketing, social marketing, content marketing, electronic marketing (e-mail), mobile marketing and banner advertising (Jarvinen, Tollinen, Karjaluoto \& Jayawardhena, 2012: Eida \& El-Goharyb, 2013). However, Lurie (2006) Conversational marketing was proposed to be an internet marketing strategy that works more direct and conservative. Conversation marketing ensures that a person get to know their audience, target them with a message, observation of respondent is put into consideration not forgetting the aspect of adjustment of the message all this is done because of internet (Lurie,2006).

Based from above literature the concept of online marketing strategies has not clearly been understood. Different authors have used different constructs to measure online marketing strategies. Sarah Burke (2017) brings out the contradicting aspect of video marketing strategy as one of the construct of online marketing strategies. Similarly, Lurie (2006) puts across the aspect conversational marketing as a construct of online marketing strategy this brings out contradictions among others. This ambiguity hinders authors to have commonality on constructs of online marketing strategies. However, some of the literature has some commonality in those online marketing strategies constructs (Eida \& El-Goharyb, 2013; Jarvinen, Tollinen , Karjaluoto \& Jayawardhena, 2012). This study will adopt Sarah Burke (2017) aspect on video marketing, Lurie (2005) aspect of conversational marketing and Jarvinen, Tollinen, Karjaluoto \& Jayawardhena (2012) content marketing, email marketing aspects as measures of online marketing strategies.

\subsubsection{Market performance concept}

Empirical reviews have brought about different ways the market performance construct have been operationalized and applied in empirical work. A study by Bragg (2015) outlined the market performance measure as being institutional capture rate, market value added, insider stock buy sell ratio, earning ratio, stock options to common share ratio, cost of capital, sales to stock price ratio, price earnings ratio and capitalized rate. Similarly, Janell et $a l$, (2015); Dale Littler, (2015) Suggested market share as a measure of market performance.

Market performance is measured using market share, total sales, customer satisfaction and customer acquisition (Gunday, Ulusoy, Kilic, \& Alpkan, 2012; Rashid, 2008; Sullivan \& Dooley, 2009). A study by Grawe, Chen, \& Daugherty (2009) on the relationship between strategic orientation, innovation patterns and market performance employed sales volume growth, profit margin growth, market share growth and overall competitive position as measures of market performance. According to Clark and Ambler (2001) market performance measurements are the interrelation between marketing activities and business performance. However, Clark (1999) posit the dimensions of market performance into categories of single financial output measurement, financial measurement, input measurement and multiple measurements.

There exist some commonality by some of the literature when indicating market performance can be measure using variables such as market share, total sales, customer satisfaction and customer acquisition (Gunday et al 2012; Grawe, Chen, \& Daugherty, 2009; Rashid, 2008; Sullivan and Dooley, 2009). However, Clark (1999) brings a contradicting construct of market performance as compare to other literatures. This being a contradiction there is need for the authours to have a consesus in understanding the constructs of market performance. This study will 
adopt market performance measurements adopted from Gunday, Ulusoy, Kilic and Alpkan (2012), Rashid (2008), Sullivan and Dooley (2009), and Grawe, Chen, \& Daugherty (2009) being market share, sales, profit margin and competitiveness.

\subsubsection{Firm characteristics Concept}

Firm characteristics are conceptualized differently by different authors. A firm characteristic is a demographic and managerial variable that encompasses part of the firm's internal environment (Zou \& Stan, 1998). Review from past literature shows different ways in which firm characteristics constructs have been applied. The study on firm characteristics and empirical factors model on data mining by Kogan \& Tian (2012) outlined firm characteristics constructs included firm size, leverage, liquidity, sales growth, assets growth and turnover. Similarly, some of the firm characteristics construct included firm size, profitability, sales growth, leverage, liquidity, age of the firm, board structure and composition, assets growth, turnover and growth prospects. (Kogan \& Tian, 2012; Mule, Mukras, \& Nzioka, 2015).

From this study firm characteristics was used as a moderating variable between online marketing strategies and market performance. Moderatin variables are variables that affect the strength of relationship between the dependent and independent variables. This study adopts size of the firm and age of the firm constructs proposed by (Kogan \& Tian, 2012)

\subsubsection{Competitive advantage}

Competitive advantage is attained by a firm if it implements value creating strategy that is not concurrently implemented by other competitor firms (Barney, 1991; Porter, 1985). Low cost and differentiation are basic types of competitave advantage that a firm posses (Porter, 1985). Differentiation strategy builds up entry barriers to potential competitors by building customer and brand loyalty through quality offering and advertising (WenCheng, et al., 2011). The position of superiority within organizations that firms has developed compared to its competitors is a clear outlook of competitive advantage (Kariuki \& Kilika, 2017). However, competitive advantage aspect exist when the firm deliver the same benefit compared to its competitiors but at a lower cost or deliver benefits that outdo those of the competitors (Wen-Cheng, et al., 2011).

The study adopt competitive advantage as a mediating variable on differentiation aspect of brand positiong and customer focus. 
Table 2.1: Summary of Conceptual Literature Review

\begin{tabular}{|c|c|c|}
\hline CONSTRUCTS & UNDERSTANDING & INDICATORS \\
\hline $\begin{array}{l}\text { Online Marketing } \\
\text { Strategies }\end{array}$ & $\begin{array}{l}\text { Online marketing strategies are activities that are carried } \\
\text { out throught the connection of an internet on air. }\end{array}$ & $\begin{array}{ll}\text { - } & \text { Content } \\
& \text { marketing } \\
\text { - } & \text { Conversational } \\
& \text { Marketing } \\
\text { - } & \text { Email Marketing } \\
\text { - } & \text { Video marketing }\end{array}$ \\
\hline $\begin{array}{l}\text { Market } \\
\text { Performance }\end{array}$ & $\begin{array}{l}\text { It is utilization of scare resources by organizations to meet } \\
\text { the demand for consumers for market related goals such as } \\
\text { market share, profit and sales volume. }\end{array}$ & $\begin{array}{ll}\text { - } & \text { Profit margin } \\
\text { - } & \text { Market share } \\
\text { - } & \text { Sales Volume } \\
\text { - } & \text { Competitive } \\
& \text { position }\end{array}$ \\
\hline $\begin{array}{l}\text { Firm } \\
\text { Characteristics }\end{array}$ & $\begin{array}{l}\text { This is a demographic and managerial variable that } \\
\text { comprise part of the firm's internal environment }\end{array}$ & $\begin{array}{l}\text { - } \\
\text { - } \\
\text { - }\end{array}$ \\
\hline $\begin{array}{l}\text { Competitive } \\
\text { advantage }\end{array}$ & $\begin{array}{l}\text { An aspect tha exist when the firm deliver the same benefit } \\
\text { compared to its competitiors but at a lower cost or deliver } \\
\text { benefits that outdo those of the competitor }\end{array}$ & $\begin{array}{ll}\text { - } & \text { Customer Focus } \\
\text { - } & \text { Brand positioning }\end{array}$ \\
\hline
\end{tabular}

Source: Researcher (2019).

\section{Review of relevant theories anchoring the study}

The paper is anchored based on the theories that were relevant for conceptualization of the study, which include unified theory of acceptance and use of technology(UTAUT), the behavioral adoption theory, innovation diffusion theory, technology organization environmental framework(TOE), industrial organization theory and porters five forces model.

The UTAUT theory which was implemented by (Venkatesh, Morris, Davis \& Davis , 2003), bring about four facets which include performance expectancy, effort expectancy, social influence and facilitating condition. These four facets bring out the porters five forces model. Development of the theory was due to reviews and amalgamation of eight prominent theories and models which included TAM, the motivational model, and theory of reasoned action TRA, the theory of panned behavior TPB, a combined TPB/TAM, models of PC utilization, Innovation diffusion theory and social cognitive theory (Venkatesh, Morris, Davis and Davis, 2003). The theory is well tested, validated and found reliable.

The behavioural adoption theory encompasses three theories which are technology acceptance model (TAM), theory of reasoned action(TRA) and the theory of planned behaviour (TPB). TAM was proposed by David Fred in 1986 this model helps in the describing and forecasting of the behavior of the users of new technology. TRA was originally implemented by Fishbein and Ajzen (1975) who said that a person's behaviors are determined by 
behavioral intents which are determined by attitude, subjective norms and cultural norms. The theory anchors this study since online marketing strategies is a fairly new phenomenon internationally, these strategies are mostly simple and easy to use by those who are technologically wit (Minama, 2016).

The theory of innovation diffusion was implemented by (Rogers, 1995). Innovations referring to technologies, ideas, practices or products that are alien to the society and which are spread and shared through communication by members of the society (Rogers, 2009). This theory suggested the three main sources that influence the diffusion and adaption of an innovation includes perception of innovation characteristics, adopter's characteristics and contextual factors. The theory emphasizes that innovation spreads slowly over time and among people resulting in various adopter categories. This theory is applicable to study the online marketing strategies in such a way it could bring about significant changes to work practices and could also cause resistance to change (EL-Gohary, 2012; Grandon \& pearson, 2004).

The TOE framework was evolved by (Tornatzky \& Fleischer, 1990). It addresses three main facets that show the relationship between factors associated with the organizational context such as innovativeness, organization adoption of technology innovations, environmental context like competitor pressure and technological context such as complexity. The organization context contains internal issues of an organization such as employee, management products and services, technological context include characteristic and usefulness of both internal and external innovation technology that are of important to the organization. Studies relating to internet marketing strategies support the use of this framework. TOE framework therefore, is widely used in adoption of different innovative strategies and proven to be valid (Ramdani \& Kawalek, 2007).

Industrial organization theory was implemented by (Hymer, 1976). According to this theory when a firm is to establish a substitute in another country or market, it faces several challenges as regards to competition that comes along with the local firms. These challenges emanates from things like differences in language, culture, legal system and other inter-country differences or inter-market differences. For this reasons the firm has to have some advantages to enable it compete with the already established local firms. The industrial organization theory is applicable to market performance variable because in this we are able to show how the performance of a firm is brought in different market segments. The issues on building on brand recognition, price differentiation and promotional activities comes in handy when implementing a product in another market.

Porter's five forces model was introduced by (Porter,1980), to explain the forces that shape competition in an organization. Porter identified five forces of competition being; threat of new entrants, threats of substitutes, bargaining power of buyers, bargaining power of suppliers and competitive rivalry in the industry. The strengths that come with this constructs are the determining factors of profit and sales potential of an organization (Thompson \& Strickland, 2003). Therefore for an organization to gain competitive advantage they have to seek resources that are valuable, rare, inimitable and non-substitutable. The theory is applicable to market performance variable since organizations require resources to enable then acquire process, analyze, disseminate and implement competitive advantage.

\subsection{Empirical review}

\subsubsection{Content marketing and market performance}

Human, Hirschfelder \& Nel (2018) conducted a study on the effects of content marketing on sponsorship 
favourability in South Africa specifically cape town area. The reasons for conducting this study was to show the effects of content marketing on sponsorship-response favorability in south africa energy drink market. A sample of 45 repondents were asked to fill a quesionaire both males and female between the age of 18-35 years old. The group discussion was also conducted to obtain feedbacks on the questionnaire. Non-probability convienience sampling was applied. The use of theorized content marketing sponsorship model, six independent and one dependent variable were operationalized and measured using seven-point likert scale. The structural equations modeling approach (SEM) was applied for data analysis. the findings showed that the acceptable model was fit and useful to understand the relationship of content marketing and sponsorship favourability.

Similary, a study by Fujita, Harrigan and Souta (2019) on the strategic co-creation of content and student experience in social media: an identity theories perspective, the study was of the purpose to enhance the understanding of how co-created content can influence relevant and meaningful customer experience in social media brand communities. The study employed social indentity theory and social indetification theories. Netnography used to analyse data. The finding of the study were such that the analysis of co creation content had a positive effect of identity narrative and cues that can be grouped into university, sub group and student role identity theme.

\subsubsection{Conversation marketing and market performance}

Rader, et al., (2014) conducted a study on emerging social media marketing strategies for pharmaceuticals in USA. The study was for the purpose of indentifying quality online converstation among consumers and potential constituted as pertains to pharmaceutical marketing and show exploratory empirical studies based on qualitative data to current state pharmaceutical marketing and consumer activities within social media marketing strategies. Pradigm philosophy was emplyed in the study. Data was collected through netnography technology and explanatory framework used. The results showed that significantly persuasive bonding and impactful among consumers, bloggers about pharmaceutical offering is widespread.

Rubin, Chen \& Thorimb (2010) did a study on intelligent conversation agents in libraries in Canada. The purpose of the study was to investigate the current state and applications of conversational agents wordwide while forcusing on availability in canadian libraries. A web website of 20 largest canadian libraries were used for sample and survey data collection method applied. Pragmatic philosophy was used in this study. The study aimed to argue that time and conceivable for canadian libraries were considered to adopting conversational agents. The findings indicated that the artificially intelligent conversational systems does not exist in canadian libraries and other innovation technologies proliferate such as social media tools.

\subsubsection{Email Marketing and market performance}

According to Reimers, Chao \& Gorman (2016) the study on permission email marketing and its influence on online marketing strategies carried out in Mebourne Australia, the purpose of the study was to show the influence of email marketing on perceived value dervived from internet marketing. They considered theories such as technology acceptance model (TAM). The target population was aldult consumers residing in Melbourne, Australia who purchase online for their clothes.Data was collected through online survey in Mebourne Australia. A sample of 338 consumers was used. Exploratory and confirmatory factor analysis were used, and Structural equation modelling (SEM) was used to test conceptual framework variables. The study results indicated that email marketing had a positive influence on perceived usefullness, ease of use and enjoyment derived from shopping 
online.

Further, Baek and Morimoto (2013) conducted a study on the topic stay away from me in England and wales examining the deternimants of consumer avoidance of personalized advertising. The study was conducted to examine the key factors that influence personalized advertising avoidance and investigate how such processes may differ across a variety of advertising formats such as email, telephone calls and text messages. Data was collected using online survey data collection method. A sample size of 442 participants was used and the structuraal equation modelling (SEM) was used tor the analysis. The findings showed that both irritations and privacy concers had an effect on avoidance and increased perceived personalization lead to decraese in avoidance. The findings from this study are generalized limited because they use a students sample.

\subsubsection{Video marketing and market performance}

Martin (2012) conducted a study on one minute video; marketing your library to faculty. The reason for carrying out this study was to investigate how a succesfull streaming video communication effort developed at the California states University, Northridge Oviatt Library to reach out to campus faculty. Therefore the study aims to discuss other library video collaborations for the purpose of marketing the library resources and services in academic setting. Survey is used as a data collection method which consisted of ten questions, six closed and four open ended questions. And the survey return rate composed of 31 responses. The findings of the study indicated that collaboration among campus faculty and other departments within the university played a large role in team ability to develop the video campaign.

Similary, Evuleocha (2008) did a study on Nollywood and home video revolution: implications for marketing videofilm in africa. The purpose for conducting this study was to evaluate the implications for marketing video film in Africa and examine the structure of the industry. The study was carried out in Nigeria. The study used a case study method to show how technological innovation aspects are being used in ways that has never been imagined or intended by the innovators. The findings of the study have implications that they provide a template for practitioners to engage in future research in video films in africa.

From above empirical reviews this paper has empirical gaps in that no studies have been conducted on the effect of content marketing, conversational marketing, email marketing and video marketing on market performance. Further, the study was conducted in other contextual aspect and countries as compared to the proposed contextual aspect. 


\section{Recommended Conceptual Framework}

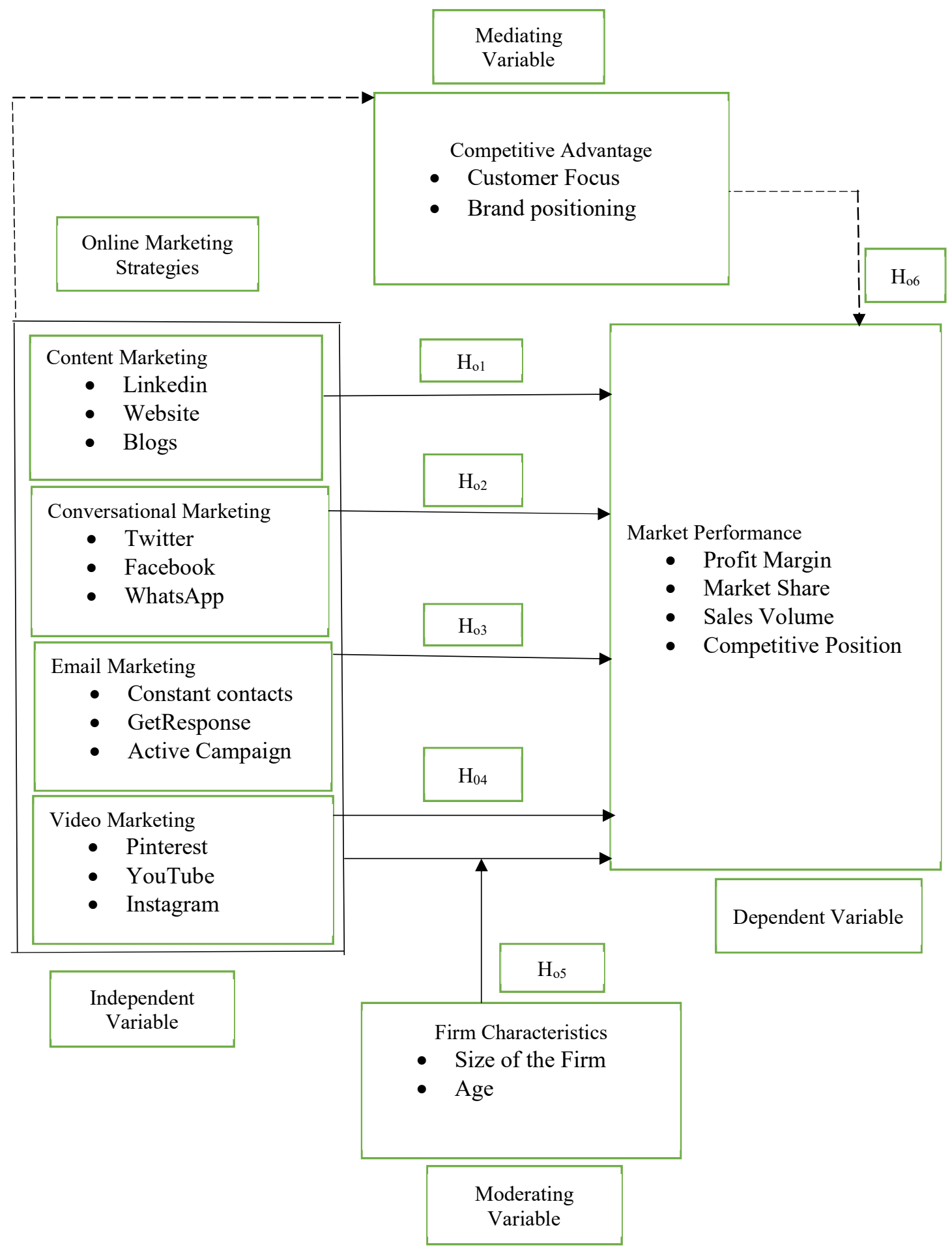

Source: Researcher (2019) 
From the above conceptual framework it indicate that online marketing strategies as the proposed independent indicator of Market performance. Online marketing strategies have been integrated by a couple of items that include content marketing, email marketing, video marketing and conversation marketing. Similarly, online marketing strategies are affected by the external factors such as firm characteristics and competitive advantage.

\subsection{Recommended Research hypothesis}

From the above conceptual framework, it is further proposed empirical study should be carried out as being online marketing strategies as an independent variable, market performance as a dependent variable, competitive advantage being mediating variable and firm characteristics as moderating variable. Therefore it will be guided by the following proposed research hypothesis.

Ho1: Content marketing has no significant effect on market performance

Ho2: Conversational marketing has no significant effect on market performance

Ho3: Email marketing does not have significant effect on market performance.

Ho4: Video marketing has no significant effect on market performance

Hos: Firm characteristics has no significant moderating effect on the relationship between online marketing strategies and Market performance

Ho6: Competitive advantage has no significant mediating effect on the relationship between online marketing strategies and Market performance

\subsection{Recommended Contextual aspect}

This study will be limited to study of tours and travel agencies in Nairobi Kenya. The unit of analysis will be tours and travel agencies in Nairobi and unit of observation will be the top managers in those tours and travel agencies. Despite increased number of tour and travel agencies in Nairobi their performance in terms of sales and market share are minimal. Some of the tours and travel agencies in Nairobi are performing better than others in terms of competition. This therefore is a problem that needs to be studied to enable the managers of the tours and travel agencies that are not performing well in term of market share improve on their competitive advantage aspect.

\subsection{Recommended methodology}

This study recommends positivism philosophy as the most suitable philosophy. Positivism drives quantitative outlook that holds there is an objective reality that can be expressed numerically with explanatory and predictive power (Furre, et al., 2008). This recommends adoption of mixed method research designs. Saunders, Lewis and Thornhill (2009) combining different designs in one study enables triangulation in addition to increasing the validity of the findings to achieve optimal results. A five point linkert scale semi-structured questionnaire data collection method will be used whereby they will be administered via drop and pick unlike other studies which contradicts by using seven point linkert scale survey method (Human, Hirschfelder, \& Ne, 2018 : Psomas, Kafetzopoulos and Gotzamani, 2017).

Stratified sampling method will be used for sampling. The stratified sampling method measures the overall population parameters with greater precision and ensures an extraction of a representative sample from a relatively homogenous population (Kothari, 2004). The use of Structural equation modelling (SEM) is applied by past 
lieratures from the previous studies. (Human, Hirschfelder, \& Ne ,2018: Reimers, Chao, and Gorman, 2016: Baek and Morimoto, 2013: Lacey, 2012). This study reccomends the use of multiple regression method. However, this study will employ the use of descriptive statistics and inferential statistics with the help of Statistical Package for Social Sciences (SPSS) version 20 to achieve the objectives of the study. Factor analysis will be used to test indicators of online marketing strategies against market performance.

\section{Conclusions and recommendations}

\subsection{Conclusions}

Based on the theories discussed, the study conclude, Unified theory of acceptance and use of technology, behavioral adoption theory, innovation diffusion theory, technology organization environmental framework and industrial organization theory are significant theories that are used for discussion of online marketing strategies and market performance. However, industrial organization theory has been used for other performances such as financial, firm and organization performance which has not been clearly classified under what performance it should stand out.

The study recommends from the empirical and theoretical gap online marketing strategies as an independent variable, market performance as dependent variable, firm characteristics as a moderating variable and competitive advantage as mediating variable.

The study recommends a knowledge gap in the area of online marketing strategies and market performance. This shows the market performance as an effect of online marketing strategies. Therefore, online marketing strategies have a significant relationship towards the market performance. Further the study proposed the contributions in the field of online marketing strategies concerning factors that influence market performance. The study also recommends other contextual aspect regarding to the content of the study.

\subsection{Recommendations}

The study was conducted on the online marketing strategies and market performance but similar studies would be conducted on other variables apart from the one discussed to show their relationship and also including the contextual aspect. Organizations should consider the aspect of competitive advantage when introducing their products into new markets. Further the study the firms should consider other marketing strategies to show their effect on market performance. Lastly, the other studies should consider bringing in other mediating and moderating variables other than those proposed for this study.

\section{REFERENCES}

Aleksandar, G. \& Olja, M., 2017. The Many Faces of Internet Marketing. Dubrovnik, IRENET - Society for Advancing Innovation and Research in Economy, pp. 412-417.

Baek, T. H. \& Morimoto, M., 2013. Stay away from me. journal of advertising, Vol 41, No 1, pp. 59-76. 
Barone, M. J. \& DeCarlo, T. E., 2012. Performance Trends and Salesperson Evaluations: The Moderating Roles of Evaluation Task, Managerial Risk Propensity, and Firm Strategic Orientation. Journal of Personal Selling \& Sales Management, vol 32, issue 2, pp. 207-223.

Davis, F. D., 1989. Perceived Usefulness, Perceived Ease of Use, and User Acceptance of Information Technology. MIS Quarterly, Vol. 13, No. 3, pp. 319-340.

Eida, R. \& El-Goharyb, H., 2013. the impact of e-marketing use on small business enterprises'marketing success. Service Industries Journal, vol 33, issue 1, pp. 31-50.

El-Gohary, H., 2010. E-Marketing - A literature Review from a Small Businesses perspective. international journal of business and social science, Vol. 1 No. 1, pp. 214-224.

Evuleocha, S. U., 2008. Nollywood and the home video revolution: implications for marketing videofilm in Africa. International Journal of Emerging Markets, Vol. 3, Issue: 4, pp. 407-417.

Fishbein, M. \& Ajzen, I., 1975. elief, Attitude, Intention, and Behavior: An Introduction to Theory and Research. Addison-Wesley: MA.

Fujita, M., Harrigan, P. \& Souta, G. N., 2019. The strategic co-creation of content and student experiences in social media: An identity theories perspective", Qualitative Market Research. An International Journal, Vol. 22, Issue: 1 , pp. 50-69.

Furre, O., Thomas, H. \& Gousserskala, A., 2008. The Structure and Evolution of the Strategic Management Field: A content Analysis of Twenty six years of Strategic Management Research. International Journal of Management Reviews, Vol 10, No 1, pp. 1-23.

Grawe, S. J., Chen, H. \& Daugherty, P. J., 2009. The relationship between strategic orientation, service innovation, and performance. International Journal of Physical Distribution \& Logistics Management, Vol 39, Issue 4, pp. 282-300.

Gunday, G., Ulusoy, G., Kilic, K. \& Alpkan, 2012. "Effects of innovation types on firm performance. Science Direct.

Human, G., Hirschfelder, B. \& Ne, J., 2018. The effect of content marketing on sponsorship favorability. International Journal of Emerging Markets, Vol 13, Issue: 5,, pp. 1233-1250 .

Hymer, S., 1976. The international operations of national firms : a study of direct foreign investment. Massachusett: MIT Press.

Jarvinen, J., Tollinen, A., Karjaluoto , H. \& Jayawardhena, C., 2012. Digital and social media marketing usage in B2B industrial section. Marketing Management Journal, Vol 22, issue 2, pp. 102-117.

Kariuki, J. \& Kilika, J. M., 2017. Organization Capability, Innovation and Competitive Advantage:An Integrative Theoretical Framework Review of Literature. The International Journal Of Business \& Management, Vol 5 Issue 2, pp. 42-51.

Kogan, L. \& Tian, M. H., 2012. Firm characteristics and empirical factor models: a data-mining experiment. s.1., S.n.

Kothari, C. R., 2004. Research Methodology: Methods and Techniques. 2nd Edition. New Delh: New Age International Publishers.

Kumar, V. \& sharma, R. R., 2017. Relating management problem-solving styles of leaders to TQM focus: an empirical study. The TQM Journal, Vol 29, No. 2, pp. 218-239. 
Lacey, R., 2012. How customer voice contributes to stronger service provider relationships. Journal of Services marketing, Vol 26, Issue 2, pp. 137-144.

Lurie, I., 2006. Conversation Marketing: Internet Marketing Strategies. Washington: Trafford Publishing.

Martin, C. M., 2012. One-minute video: marketing your library to faculty. Reference Services Review, Vol. 40, Issue: 4, pp. 589-600.

Monnappa, A., 2018. History and Evolution of digital marketing.

Mule, , R. K., Mukras, M. S. \& Nzioka, O. M., 2015. Corporate size, profitability and market value: an econometric panel analysis of listed firms in Nairobi. European Scientific Journal,vol 11, No 13, pp. 1857-7881.

Omar, M., Bathgate, I. \& Nwankwo, S., 2011. Internet marketing and customer satisfaction in emerging markets: the case of Chinese online shoppers. An International Business Journal, Vol. 21 Issue: 2, pp. 224-237.

Porter, M. E., 1980. Competitive Strategy. New York: Freepress, McMillan.

Porter, M. E., 1985. Competitive Advantage. New York: The Free Press.

Psomas, E., Kafetzopoulos, D. \& Gotzamani, K., 2017. Determinants of company innovation and market performance. The TQM Journal, vol 30,issue 1, , pp. 54-73.

Rader, C. S. et al., 2014. Emerging social media marketing strategy for pharmaceuticals. International Journal of Pharmaceutical and Healthcare Marketing, Vol 8, Issue 2, pp. 193-225.

Rashid, S., 2008. Impact of organizational culture on customer satisfaction: a study of practitioners in public relation and corporate communication industry in Malaysia. Unpublished Thesis International Islamic University Malaysia, Kuala Lumpur.

Reimers, V., Chao, C.-W. \& Gorman, S., 2016. Permission email marketing and its influence on online shopping. Asia Pacific Journal of Marketing and Logistics, Vol 28, Issue 2, pp. 308-322.

Rogers, E. M., 1995. Diffusions of innovations. New york: Fress press.

Rubin, V. L., Chen, Y. \& Thorimb, L. M., 2010. Artificially intelligent conversational agents in libraries. Library Hi Tech, Vol 28, Issue: 4, pp. 496-522.

Salindal, N. A., 2018. Halal certification compliance and its effects on companies' innovative and market performance. Journal of Islamic Marketing.

Saunders, M., Lewis, P. \& Thornhill, A., 2009. Research methods for business. London: Pearson Education lt.

Smith, P. R. \& Chaffey, D., 2008. E-Marketing excellence (emarketing essentials). New York: Routledge Taylor and Francis Group.

Sullivan, O. D. \& Dooley, L., 2009. Applying Innovation. Los Angeles: Sage Publication.

Thompson, A. A. \& Strickland, A. J., 2003. Strategic Management-Concepts and Cases -13thed.. New York: McGraw-Hili.

Tornatzky, L. \& Fleischer, M., 1990. The process of technology innovation. Lexington: MA.

Venkatesh, V., Morris, M. G. \& B, G., 2003. User Acceptance of Information Technology: Toward a Unified View. MIS Quarterly Vol. 27, No. 3 , pp. 425-478.

Wen-Cheng, Chien-Hung \& Ying-Chien, 2011. Types of Competitive Advantage and analysis. International Journal of Business and Management Vol. 6, No. 5.

Zapata-Cantu, L., 2016. Resource and dynamic capabilities in business excellence models to enhance competitiveness. The TQM Journal, Vol. 28 Issue: 6, pp. 847-868. 
Zou, S. \& Stan, S., 1998. The determinants of export performance: a review of the empirical literature between 1987 and 1997. International Marketing Review, Vol. 15 No. 5, pp. 333-356. 